アミノアンスラキノン系分散染料と $\beta$-ナフタリンスル ホン酸ーホルマリン縮合物ナトリウム塩との相互作用*

\author{
锿州大学樴維学部 墨岩茂 隆・小笠原真次 \\ 平野荘二・沓沢さち子
}

\title{
INTERACTION BETWEEN AMINOANTHRAQUINONE DISPERSE DYES AND SODIUM $\beta$-NAPHTHALENE SULFONATE-FORMALDEHYDE CONDENSATES
}

By Shigetaka Kuroiwa, Shiüji Ogasawara, Soji Hirano and Sachiko Kutsuzawa

(Faculty of Textile, Shinshū University, Ueda City, Nagano Prefecture, Japan)

\begin{abstract}
Interaction between aminoanthraquinone disperse dyes and sodium $\beta$-naphthalene sulfonateformaldehyde condensates in aqueous medium has been investigated with the continuous variation method in optical density and electroconductivity. Samples used were 1-amino-, 1, 4-diamino- and $1,4,5,8$-tetraaminoanthraquinone, and two condensates whose degrees of condensation were $2 \sim 3$ and $8 \sim 10$, respectively. These disperse dyes interacted to form the $1: 1$ complexes with each naphthalene nucleus of the condensate independently of its degree of condensation. These experimental results suggest that this complex may be formed by van der Waals interaction between anthraquinone nucleus of the dye and naphthalene nucleus of the condensate.
\end{abstract}

(Received June 23, 1970)

\section{1. 緒言}

ßテナフタリンスルホン酸のホルマリン濰合物ナトリウ 么塩は，すぐれた水中分散剮の一つとして知られてお りすでに実用されているが，これに関する基礎的研究 は意外に少ない。たと文ば根来らははこの分散凧は縮 合度の高いものほと，炭酸カルシウムの分散性がよくな ること安指摘し，服部・谷野2は，バット染料の上5な 有機物を分散させる䑼合には，1核体と5核体以上の混 合物が有效であると報告している。しかしこれらはいず れる，分散剤の構造または組成と分散力に関するるのて あり，その分散機構については汪とんど不明のままであ る。とくに，この $\beta$ ーナフタリンスルホン酸・ホルマリ ン樎合物ナトリウ塩が，分散染料の分散剂として使用さ れる場合の分散機棈，あるいは染料との相互作用機棈に いたってははったく不詳であるといるざるを得ない。 著者らはこの点に関する基礎的知見をうることを目的と して，三，三のアミノアンスラキノン系分散染料と，縮 合度の異なる 2 種の $\beta$ ーナフタリンスルホン酸 ・ホルマ リン縮合物ナトリウム塩とを実験の試料とし，これらの

*この報交を「染料の分散状熊と染色性に関する研究 (第 6 報) Studies on the dispersed state of dyes and their dyeing properties (VI)」とする。
水溶腹中での相互結合比少連統変化法によって求め, 相 互作用機構について若年の考察を試みた。

\section{2. 実 験 試 料}

\section{1 分散染潾}

本笑験に使用したアミノアンスラキノン系分散染料は 表1に示した 3 種である。これらは三药化成工策怢式会 社から提供されたものであるが，いずれ死融点が一定に なるまで，アセトンによる再結晶をくりがして精整 し，さらにペーパークロマトグラフ法で，ただ個の明 確なスポット亲示すことを確認した上で，実駼使用し た。广おこれら染料の水溶液は微結唱溶解法 ${ }^{7,8)}$ に上り， 恋た分散液（サスペンジョン）はとくに坞一状態のもの 至5るために，これに超音没分散法8）併用して調製し to

$$
\begin{aligned}
& 2 \cdot 2 \beta \text {-ナフタリンスルホン酸・ホルマリン縮合物 } \\
& \text { ナトリウム塩 }
\end{aligned}
$$

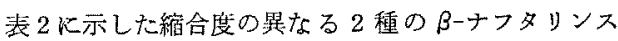
ルホン酸・ホルマリン繀合物ナトリウム壏（以下 $\mathrm{NaN}$ SF と略記する）光，本実騟の試料として用いた。これ らは明成化学工菜株式会社研究室に特いて合成,ならび に精变されたものである。表中カッ二内の数字はそれぞ

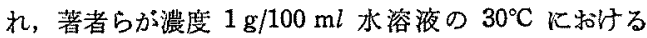


Table 1. Aminoanthraquinone disperse dyes

\begin{tabular}{|c|c|c|c|c|}
\hline Structure & Abbreviation & $\begin{array}{l}\text { m.p. } \\
\text { Obs. }\end{array}$ & $\stackrel{\left({ }^{\circ} \mathrm{C}\right)}{\text { Lit. }}$ & $\begin{array}{c}\lambda_{\max }{ }^{7)} \\
(\mathrm{m} \mu)\end{array}$ \\
\hline
\end{tabular}<smiles>NC1CCC(N)C2C(=O)C3C(N)CCC(N)C3C(=O)C12</smiles>

$\begin{array}{llll}1,4,5,8-\mathrm{NH}_{2} & 330-334 & 320-330^{3)} & 570 \\ 615\end{array}$<smiles>N[C@H]1CC[C@@H](N)C2C(=O)C3CCCCC3C(=O)C21</smiles>
$\begin{array}{llll} & & 261^{4)} & \\ 1,4-\mathrm{NH}_{2} & 265 & 262^{53} & 546 \\ & & 268^{63} & 585\end{array}$<smiles>NC1CCCC2C(=O)C3CCCCC3C(=O)C12</smiles>

$1-\mathrm{NH}_{2}$ 25
Table 2. Condensates of sodium $\beta$-naphthalene sulfonate and formaldehyde

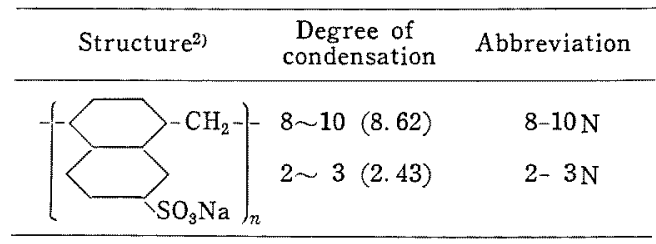

数度測定から，服部・谷野の粘度式文を用いて求めた平 均の縮合度である。またこれら NaNSF の漶度はここ ではすべて箱合体の平均の分子量を平均の縮合度で除し た䛧，したがって核体 1 個むたりのモル濃度であらわす ことにする。縮合体の平均分子量を粘度澌定によって求 めると，当然粘度平均をうることになり，数平均分子量 との間に差があるのか゚一般であるが，澧度のとり方をこ のようにすると，結果に与える影響はきわめて小さく， それははとえど無視することができる(平均分子量（ま たは縮合度）にかりに 50\%の差があったとしても，結 果に与党る影響は1\%以下（縮合度が高い場合任と小さ い) である)

いら亲であなく，分散染料の分散凨として用いられる 通常の界面活性剤は，ある特定浀度 (CMC) 以上でミセ 几を形成するがこの NaNSFはミれルを形成しない ものとされている り, $10^{-5}$ から $10^{-2} \mathrm{~mol} / l$ の濃度籁囲にわたって調に゙た 結果でも，比電気伝導度対浱度曲線に CMC K相当する
屈折点はみとめられず，やはりミせル形成 はないるのと判断された。

\section{3. 実 験 方 法}

各試料液の吸收スペクトル屯たは吸光度 の測定ならびに電気伝尊度の測定は，既 報 ${ }^{8\rangle}$ 之まったく同様の方法によるので，説 明を省略する。ただし, 光学的連秸变化法 による結合比の決定には，それぞれ表 1 に 示した染料の最大吸收波長（2個ある昜合 には長波長側）の光を使用した。また㬰歌 は，電気伝筧度の測定を $25 \pm 0.03^{\circ} \mathrm{C}$ の恒 温水槽内で行なった以外は，すへて室温で 行なった。

\section{4. 実験結果および考察}

はじめに，それ卆れ表1扰よび表 2 に示 したアミノアンスラキノン系分散染料と NaNSF とが，水溶液中ではたして相互結 合体を形成しらるか否か知るために，それぞれ染料淟度 を一定 $\left(5 \times 10^{-7} \mathrm{~mol} / \mathrm{l}\right)$ とし，種々の害合に NaNSF を 添加した溶液の吸収スペクトルを测定した。その結果， いずれの場合もスペクトルに等吸収点があらわれ，それ ぞれ一定組成の結合体を形成することるみとめた。一例

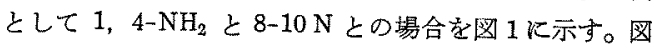
からこの系では 515 㧊よび $605 \mathrm{~m} \mu$ 付近に等吸収点があ ること，就よび最大吸收波長は，NaNSFを $5 \times 10^{-5}$ $\mathrm{mol} / l$ 程度末で添加しても，はとんど変化しないことが

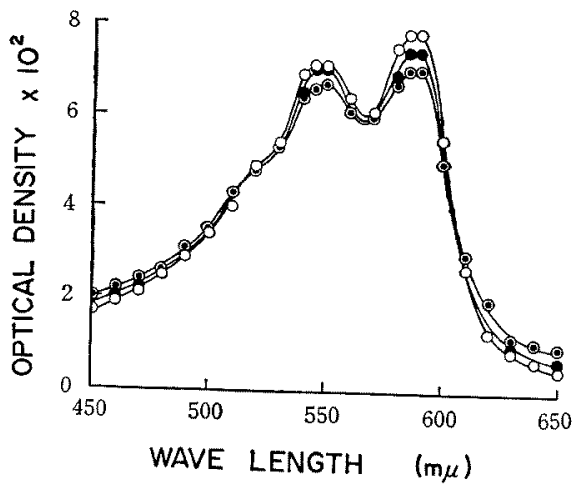

Fig. 1. Absorption spectra of $5 \times 10^{-7} \mathrm{~mol} / \mathrm{l} 1$, 4diaminoanthraquinone aqueous solutions containing various amounts of $8-10 \mathrm{~N}$ Concentration of 8-10 N
O $0 \mathrm{~mol} / \mathrm{l}$
$1 \times 10^{-5} \mathrm{~mol} / \mathrm{l}$
(-) $5 \times 10^{-5} \mathrm{~mol} / \mathrm{l}$ 
わかる（実験は染料濃度の非常に希薄な溶液について行 なわなければならない関係上，得られる光学密度の值も 低く，加 NaNSF の添加によるスペクトル変化す小さ い。したがって NaNSFを染料に対し $10^{2}$ 倍昰て添加し て実験を行なったが（添加量 $1 \times 10^{5} \mathrm{~mol} / l$ 以下の曲線 は，図の複雑化をさけるため省略した）、いずれにして る綿密な測定によって，光学密度のかなり低いところで も，实験愦差を数\%以内に扣さ劣ることがでさるので， 等吸収点の存在は確笑であると判断される。

次にこの結合体の組成比を求めるために，染料と $\mathrm{Na}$ NSF の全湲度子 $1 \times 10^{-6} \mathrm{~mol} / \mathrm{l}$ として, 北学的連続变 化法による车験を行なった。図2は分散剂として縮合度 の高い8-10 N を用いた輅合の垫䀶結果であり，図 3 は 縮合度の低い2-3Nを用いた場合のそれである（雨図と も旗軸に光学密度をとった）。実駼の結果は，染料の化

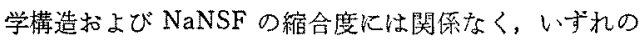
昜合6曲線は染料モル分率 0.5 の点で屈折し, 組成比 1 ：1 の結合体を形成することを示している。ただしこ

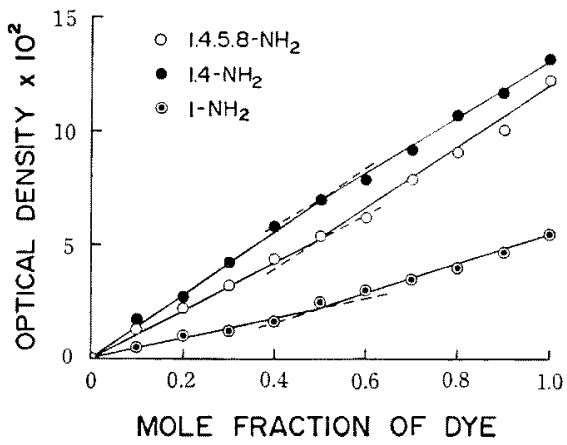

Fig. 2. Complex formation by dyes and $8-10 \mathrm{~N}$ in aqueous solutions; total concentration of dye and $8-10 \mathrm{~N}$ is $1 \times 10^{-6} \mathrm{~mol} / \mathrm{l}$.

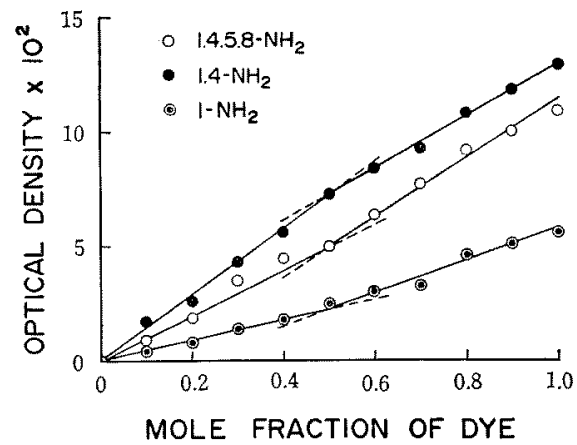

Fig. 3. Complex formation by dyes and $2-3 \mathrm{~N}$ in aqueous solutions ; total concentration of dye and $2-3 \mathrm{~N}$ is $1 \times 10^{-6} \mathrm{~mol} / \mathrm{l}$.
で NaNSF の濃度は，上述したように，1核体あたりの モル濃度であらわしている。したがって組成比 $1: 1$ の 結合というのは，染料分子と NaNSF の核体 1 個とが， 1:1 の割合で結合することを意味している。

図 4 特よび図 5 は，分散剂として 8-10 N を用い，吕 れぞれ染料と分散郕との全濃度を $5 \times 10^{-7} \mathrm{~mol} / l$, 打よび $2 \times 10^{-6} \mathrm{~mol} / \mathrm{l}$ とした場合の実駼結果である（図4K1$\mathrm{NH}_{2}$ についての結果を示さなかったのは，吸光度が低す

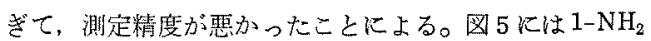
の結果とともに，1４- $\mathrm{NH}_{2}$ にいててののもあわせ示し た。これは，图 2 蛙よび図 3 の結果が，染料濃度 $5 \times$ $10^{-7} \mathrm{~mol} / l$ (染料モル分率 0.5 ) 付近を境にして，染料の

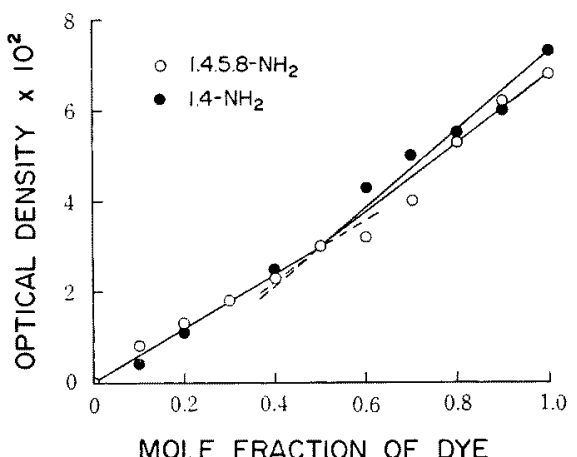

Fig. 4. Complex formation by dyes and $8-10 \mathrm{~N}$ in aqueous solutions; total concentration of dye and $8-10 \mathrm{~N}$ is $5 \times 10^{-7} \mathrm{~mol} / l$.

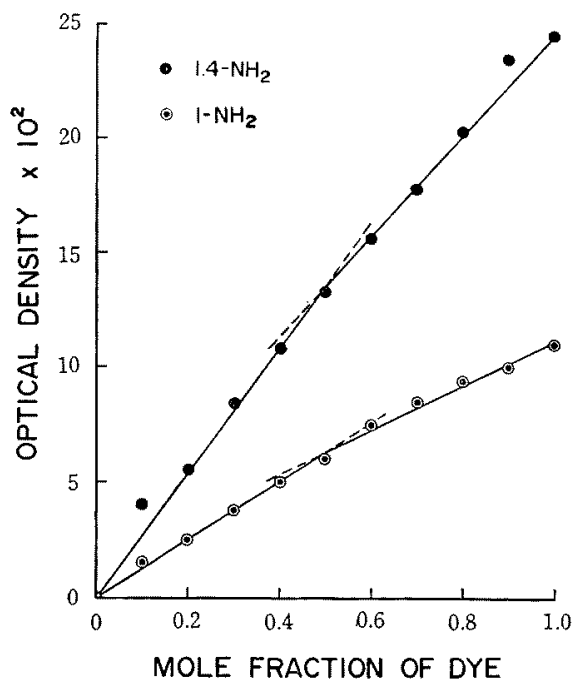

Fig. 5. Complex formation by dyes and $8-10 \mathrm{~N}$ in aqueous solutions; total concentration of dye and $8-10 \mathrm{~N}$ is $2 \times 10^{-6} \mathrm{~mol} / l$. 
分散状態が異なることによるものではないことを確かめ るために, 全澧度を変えて行なったものである。得られ た結果は図 2 扣よび図 3 とまったく同様で, 曲線は染料 と分散剤との全濃度には関係なく, 染料モル分率 0.5 の 点で屈折し，それは染料の分散状態が異なることによる ものではなくて, やはり染料と NaNSF との相互結合に もとずくものであることが確認された。

著者らはこの他にも, 全濃度 $1 \times 10^{-5} \mathrm{~mol} / \mathrm{l}$ の分散液 について同様の実験を行なった。アミノアンスラキノン 系分散染料の水に対する溶解度は，一般に $1 \sim 2 \times 10^{-6}$ $\mathrm{mol} / l$ 程度であるとされているので，この采は明らかに サスペンジョン系ということになる。しかし結果はどの 染料についても同じよ5に, NaNSF と 1:1 の結合を することを示し(圥長をさけるため図は省略), 分散阂 として，ドデシルペンゼンスルホン酸ソーダを使用した 既報8)の結果とまったく同様であった。ただし光学密度 対染料モル分率曲線が上に凸になる場合と，反対に下に 凸になる場合とがある。その理由については詳細は目下 のところ不明であるが，図 2〜5をそれぞれ比較する と, 染料濃度が大になると, 曲線は上に凸になる傾向が あるよ5に思われる。

図6は $1,4-\mathrm{NH}_{2}$ を例にとり，全濃度 $1 \times 10^{-6} \mathrm{~mol} / \mathrm{l}$ で電気伝導度測定による連続変化法を適用した結果であ る。図から明らかなよ5にこの昜合も比電気伝導度曲線 は，使用した NaNSF の縮合度には関係なく，染料モル 分率 0.5 の点で屈折し, 組成比 $1: 1$ の結合体を形成す るという上述の光学的方法による結果を支持している。 ただ図 6 をみると，8-10 N の場合と 2-3 N の場合とで

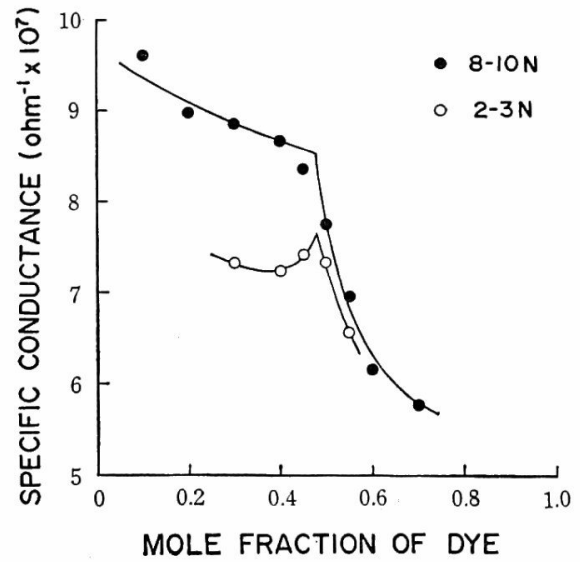

Fig. 6. Plots of specific conductance of 1,4-diaminoanthraquinone solution containing NaNSF against mol fraction of dye ; total concentration of dye and NaNSF is $1 \times 10^{-6} \mathrm{~mol} / l$.
同じものでも曲線の形が異なる。これは, 縮合度が低い 場合には NaNSF が低分子電解質的挙動をするのに対し (既報8)の図 5 を参照)，縮合度が高くなると次第に高分 子電解質的になることによるものであろ う2)。

相互結合体の組成比の決定に光学的方法を適用すると， 結合体形成に関する熱力学的諸量を求めやすいという利 点があるが, 本実験では, 図 2〜5 からもわかるよ5 に，吸光度の変化がきわめて小さいため，それを求める ことは精度的にかなり困難である。しかし本実験によ り,アミノアンスラキノン系分散染料は NaNSF の核体 1 個あたりと $1: 1$ の結合をし，アミノ基の数および NaNSF の縮合度に左右されないといらことが明らかと なった。また，結合体形成による吸光度の変化が小さい ということは，これら染料と NaNSF とは比較的低エ ネルギーの結合をすることを示唆するものと思われる。 したがってこれらの諸事実から判断すると，それは染料 のアンスラキノン核と, NaNSF のナフタレン核とのフ ァンデァワールス結合ではないかと想像される。

図 7 は，NaNSF の核体 1 個あたりとアミノアンスラ キノン系分散染料との $1: 1$ の結合が，立体的にも可能 であることを示す分子模型である。実験は十分に希薄な 水溶液中で行なわれているので, NaNSF 分子中のスル ホン基はほとんど完全に解離しており，そのため互にで きる限り離れて位置しよ5とする結果, NaNSF 分子は

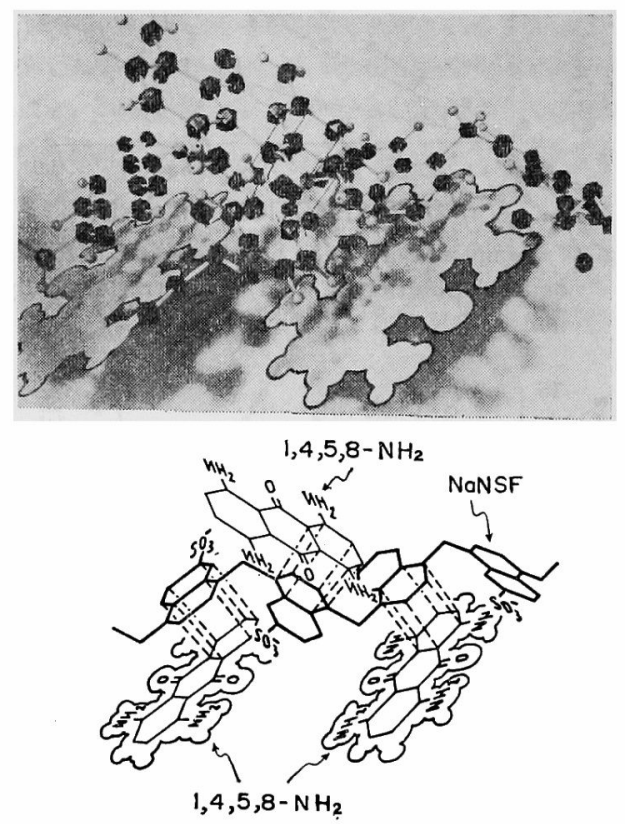

Fig. 7. Molecular model of $1: 1$ complex formed by $1,4,5,8-\mathrm{NH}_{2}$ with each naphthalene nucleus of NaNSF. 
長く引き延ばされた形態をとるものと考党られる。一方 染料分子のアンスラキノン核のうち，キノン核部分は芳 香族性がないので，実際の結合に際して性，染料分子中の ベンゼン核 I 個の部分と NaNSF 分子中のベンゼン核 1 個の部分とが，重なり合うような形で結合するものと思 われる。図 7 に示した分子模型はこのような考克に基ず いて組み立てたもので，両分子のベンゼン核部分の距嚾 は，一応グラファイトに和ける層状格子間距離 $3.44 \mathrm{~A}^{10)}$ に等しいるのとした。な技写真に示した 3 個の染料分子 のうち，左側の染料分子は NaNSF のナフタレン核中ス ルホン基を有するベンゼン核部分と，他の 2 個の染料分 子は、メチレン基でつながれた主鎖の部分のベンゼン核 そ結合した場合である。いずれにしても 1:1 の結合が 立体的に可能であることが明白である。

(昭和 45 年 4 月, 日本化学会第 23 年会飞て講演)

試料を提供していただいた三菱化成工業株式会社なら

びに明成化学工業株式会社に感謝の意を表する。

\section{文献}

1）根来煡二, 㭘山八郎, 大島敬治；工化， 62,844 (1959)

2）服部继一，谷野幸雄；工化，67，1576（1964）

3) G.S. Egerton, A. G. Roach ; J. Soc. Dyers \& Colourists, 74, 401 (1958)

4) E. H. Daruwalla, V. R. Limaye ; ibid., 74, 464 (1958)

5) 須田昌男；䄳学誌，19，143 (1963)

6) Encyclopedia of Chemical Technology, Vol. 1 p. 950 (1947)

7）墨岩茂隆，小笠原真次；工化，72，2031（1969）

8）黑岩茂隆, 小笠原真次; 穛学誌, 24,536 (1968)

9）根来煡二, 小泉久則, 須沢利郎 ; 日化第 18 年会 (1965)

10）日本化学会編，化学便覧基砋編 II, p. 1255(1966) 